\title{
Mineralization of an azo dye Acid Red 14 by electro-Fenton's reagent using an activated carbon fiber cathode
}

\author{
Aimin Wang, Jiuhui Qu*, Jia Ru, Huijuan Liu, Jiantuan Ge \\ State Key Laboratory of Environmental Aquatic Chemistry, Research Center for Eco-Environmental Sciences, \\ Chinese Academy of Sciences, PO Box 2871, Beijing 100085, China
}

Received 13 April 2004; received in revised form 14 May 2004; accepted 15 July 2004

Available online 29 September 2004

\begin{abstract}
In this paper, the comparison of activated carbon fiber (ACF) felt and graphite cathode suggested $\mathrm{H}_{2} \mathrm{O}_{2}$ might effectively be electrogenerated from $\mathrm{O}_{2}$ reduction on the large surface area ACF felt cathode, this was more adaptive for electro-Fenton process. The removal of color and total organic carbon (TOC) from simulated dye wastewater containing Acid Red 14 (AR14) was experimentally investigated using electro-Fenton reaction with ACF cathode. After 360 min of electrolysis and under the operation conditions of 0.36 A current, $1 \mathrm{mM} \mathrm{Fe}{ }^{2+}$ at $\mathrm{pH} \mathrm{3,70 \%} \mathrm{TOC} \mathrm{was} \mathrm{removed} \mathrm{as} \mathrm{well} \mathrm{as} \mathrm{complete} \mathrm{decolorization} \mathrm{occurred.} \mathrm{The} \mathrm{effect} \mathrm{of}$ $\mathrm{Fe}^{2+}$ ion concentration and applied current were also studied in detail in the experimental runs.
\end{abstract}

(C) 2004 Elsevier Ltd. All rights reserved.

Keywords: Activated carbon fiber; Electro-Fenton reaction; Acid Red 14; $\mathrm{H}_{2} \mathrm{O}_{2}$ electrogeneration

\section{Introduction}

Dyes present in wastewater are of particular environmental concern since they not only give an undesirable color to the waters but also in some cases are themselves harmful compounds and can originate dangerous byproducts through oxidation, hydrolysis, or other chemical reactions taking place in the waste phase [1]. There is a need to develop effective methods for the degradation of such organic pollutants, either to less harmful compounds or, more desirable, to their complete mineralization.

Recently, mainly because of its amenability to automation, high efficiency and environmental compatibility, there is a growing interest in the use of effective direct or indirect electrochemical degradation of organic

\footnotetext{
* Corresponding author. Tel.: +86 10 62849151; fax: +8610 62923558.

E-mail address: jhqu@mail.rcees.ac.cn (J. Qu).
}

pollutants in waters $[2,3]$. And an increasing number of papers have been published dealing with the destruction of toxic and refractory organic pollutants in acid waters by means of indirect electro-oxidation methods based on the electrogeneration of hydrogen peroxide from the two-electron reduction of $\mathrm{O}_{2}$ on the cathode [4-14]. In the presence of ferrous ions and in acidic aqueous medium the oxidation power will be enhanced due to the production of a very reactive one-electron oxidizing agent hydroxyl radical $\left(\mathrm{OH}^{*}\right) \quad\left(\mathrm{E}^{0} \quad\left(\mathrm{OH}^{*}, \mathrm{H}^{+} /\right.\right.$ $\left.\mathrm{H}_{2} \mathrm{O}\right)=2.72 \mathrm{~V} / \mathrm{NHE}$ ) from the Fenton reaction. This electro-Fenton process can generate $\mathrm{OH}^{*}$ by the simultaneous electrochemical reduction of $\mathrm{O}_{2}$ in the presence of catalytic amounts of ferrous ions [15].

$$
\begin{aligned}
& \mathrm{O}_{2}+2 \mathrm{H}^{+}+2 \mathrm{e}^{-} \rightarrow \mathrm{H}_{2} \mathrm{O}_{2} \quad \mathrm{E}^{0}=0.69 \mathrm{~V} / \mathrm{NHE} \\
& \mathrm{Fe}^{2+}+\mathrm{H}_{2} \mathrm{O}_{2}+\mathrm{H}^{+} \rightarrow \mathrm{Fe}^{3+}+\mathrm{H}_{2} \mathrm{O}+\mathrm{OH}^{\cdot} \\
& \mathrm{Fe}^{3+}+\mathrm{e}^{-} \leftrightarrow \mathrm{Fe}^{2+} \quad \mathrm{E}^{0}=0.77 \mathrm{~V} / \mathrm{NHE}
\end{aligned}
$$


$\mathrm{H}_{2} \mathrm{O} \leftrightarrow 1 / 2 \mathrm{O}_{2}+2 \mathrm{H}^{+}+2 \mathrm{e}^{-} \quad \mathrm{E}^{0}=1.23 \mathrm{~V} / \mathrm{NHE}$

While electrochemical techniques are more environmentally friendly than the chemical methods in polluted water treatment, a significant drawback is that parasitic reactions, e.g. electrolysis of water, often compete with electrolysis of the contaminants and lower the energy efficiency [16]. It is quite necessary to improve the efficiency of electrochemical techniques. Moreover, under most conditions pollutant impurities are present at such low concentrations that electrochemical processes are diffusion-controlled. The resulting diffusion-limited currents can, however, be enhanced at high-area, porous electrodes at which 2-dimensional electrochemistry is converted to "quasi-3-dimensional" behavior due to the large distributed area [17].

Activated carbon fiber (ACF) is a potential carbon material with characteristics of adsorption, conductivity and catalysis [18]. Because of its large surface area, ACF also presents high adsorption capacity and rates. And the excellent mechanical integrity makes it easily configured as a stable electrode at which electrosorption processes can be conducted for the purpose of adsorptive removal of various organic contaminants in wastewaters. Moreover, the ACF felt may be used for the electrogeneration of hydrogen peroxide from the twoelectron reduction of $\mathrm{O}_{2}$ on its surface [19].

In this paper, an electro-Fenton reaction based on ACF felt cathode was studied. We focused on systematically investigating the degradation of Acid Red 14 (AR14), a model chemical throughout the study to represent toxic contaminants with aromatic structures, by electro-Fenton process. The effect of cathode materials, $\mathrm{Fe}^{2+}$ concentration and applied current were also studied in detail in the experimental runs.

\section{Experimental}

\subsection{Materials}

The activated carbon fiber (ACF) felt was obtained from Xuesheng Technology Co. Ltd (Shandong, China), and its BET surface area, total pore volume, and mean micropore size of ACF measured by $\mathrm{N}_{2}$ adsorption using Micromeritics Model ASAP 2000 are listed in Table 1.

Acid Red 14 (AR14), a commercial azo dye, was chosen as the model compound, whose chemical structure was given in Fig. 1, and was used without further purification. Sulfuric acid, anhydrous sodium sulfate and heptahydrated ferrous sulfate were of analytical grade. Deionized and double distilled water was used throughout this study.
Table 1

Physical properties of the activated carbon fiber

\begin{tabular}{llll}
\hline Sample & $\begin{array}{l}\text { BET surface } \\
\text { area }\left(\mathrm{m}^{2} \mathrm{~g}^{-1}\right)\end{array}$ & $\begin{array}{l}\text { Total pore } \\
\text { volume }\left(\mathrm{cm}^{3} \mathrm{~g}^{-1}\right)\end{array}$ & Pore size $(\AA)$ \\
\hline ACF & 1237 & 0.1357 & 31.85 \\
\hline
\end{tabular}<smiles>O=S(=O)(O)c1ccc(N=Nc2cc(S(=O)(=O)O)c3ccccc3c2O)c2ccccc12</smiles>

Acid Red 14 (AR14)

C. I. 14720

Fig. 1. Chemical structure of Acid Red 14 (AR14).

\subsection{Procedures and equipments}

\subsubsection{Electrolytic system}

The experiments were conducted in an open, undivided cell with a capacity of about $0.55 \mathrm{dm}^{3}$, and performed at constant currents supplied by a DC power supply. The $20 \mathrm{~cm}^{-2}$ area of ACF felt was selected as cathode. A titanium grid, on the ACF felt, ensured the electric contact. The same solid surface area of $\mathrm{RuO}_{2} / \mathrm{Ti}$ mesh was selected as anode. The solution was continuously stirred with a magnetic bar (Fig. 2).

Prior to each electrolysis, the ACF felt cathode was first presaturated with $400 \mathrm{mg}^{-1}$ AR14 solution for $12 \mathrm{~h}$ to preclude the TOC decrease due to AR14 adsorption on ACF felt.

AR14 was comparatively degraded in an acidic aqueous medium containing $0.05 \mathrm{M} \mathrm{Na}_{2} \mathrm{SO}_{4}$ as supporting electrolyte and $0.2 \mathrm{M} \mathrm{H}_{2} \mathrm{SO}_{4}$ was added to adjust its initial $\mathrm{pH}$ to 3.0 using an Orion model 720APLUS Benchtop pH meter (Thermo Orion Co., USA). Solutions of $500 \mathrm{ml}$ with $200 \mathrm{mgl}^{-1}$ of initial AR14

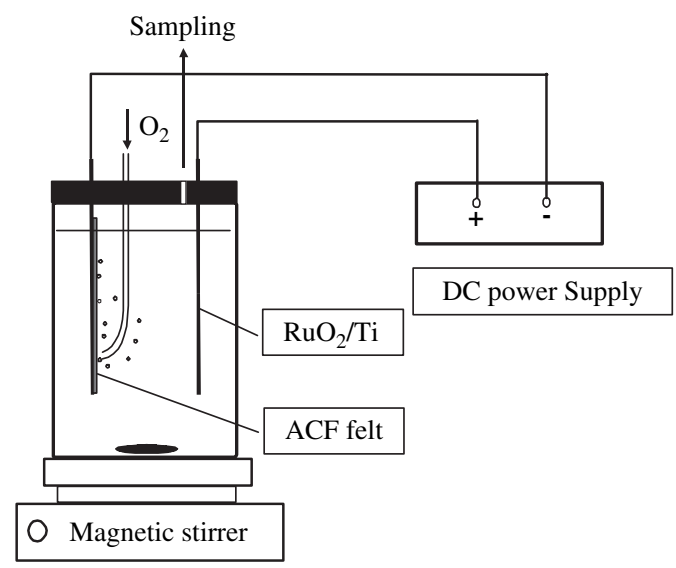

Fig. 2. Experimental setup of electrochemical reactor used for AR14 degradation. 
concentration were electrolyzed at constant current. During the electrolysis, $\mathrm{O}_{2}$ was sparged near the cathode surface to ensure the essential oxygen for electrochemical reactions. A catalytic quantity of ferrous ion was introduced into the solution before the beginning of electrolysis.

\subsubsection{Analytical method}

Samples were withdrawn from the reactor at regular time intervals $(0,30,60,120,180,270$, and $360 \mathrm{~min}$, etc.). UV-vis spectra of the samples were recorded, between 190 and $650 \mathrm{~nm}$, on a U-3010 UV-vis spectrophotometer (Hitachi Co., Japan) equipped with $10 \mathrm{~mm}$ quartz cuvettes. The decolorization of the solution was achieved by measuring the absorbance of the diluted (typically 1:4 in water) samples at $514 \mathrm{~nm}$. The total organic carbon (TOC) of the initial and electrolyzed samples was determined with Phoenix 8000 TOC analyzer (Tekmar-Dohrmann Co., USA).

Hydrogen peroxide concentrations were determined spectrophotometrically by the iodide method (detection limit of $\left.\approx 10^{-6} \mathrm{M}\right)$ as follows [20]. Aliquots $(1.5 \mathrm{ml})$ of samples were added in a $10 \mathrm{~mm}$ quartz cuvettes, and $0.75 \mathrm{ml}$ of $0.1 \mathrm{M}$ potassium biphthalate and $0.75 \mathrm{ml}$ of iodide reagent $(0.4 \mathrm{M}$ potassium iodide, $0.06 \mathrm{M} \mathrm{NaOH}$, $\approx 10^{-4} \mathrm{M}$ ammonium molybdate) were also added. Then the absorbance of the treated solution was measured with a UV-visible spectrophotometer (Hitachi 3010) at $\lambda=352 \mathrm{~nm}\left(\varepsilon=26400 \mathrm{M}^{-1} \mathrm{~cm}^{-1}\right)$.

\section{Results and discussion}

\subsection{Comparison of ACF and graphite as cathode materials}

In order to investigate the effect of cathode materials on the electro-Fenton reaction, several experiments were carried out using either ACF cathode or graphite cathode, which had the same solid surface area. Fig. 3 shows the TOC and color removal in the electro-Fenton reaction using ACF felt and graphite cathode. It was obvious that the decolorization ability of these two cathode materials was analogous, whole decolorization was achieved within $90 \mathrm{~min}$ for both the cathode materials. But their mineralization ability was much different. After $360 \mathrm{~min}$ of electrolysis, the TOC removal of ACF felt was $70 \%$, which was much higher than $40 \%$ of graphite cathode. The different mineralization ability was due to the different ability of $\mathrm{H}_{2} \mathrm{O}_{2}$ electrogeneration of these two cathode materials. Fig. 4 presents the concentration of $\mathrm{H}_{2} \mathrm{O}_{2}$ generated in the solution for these materials at $0.36 \mathrm{~A}$ and $\mathrm{pH}$ 3.0. As illustrated in Fig. 4, after $180 \mathrm{~min}$ of electrolysis, $600 \mu \mathrm{M} \mathrm{H}_{2} \mathrm{O}_{2}$ was electrogenerated with ACF felt cathode, while only $52 \mu \mathrm{M} \mathrm{H} \mathrm{H}_{2} \mathrm{O}_{2}$ was generated with graphite cathode,

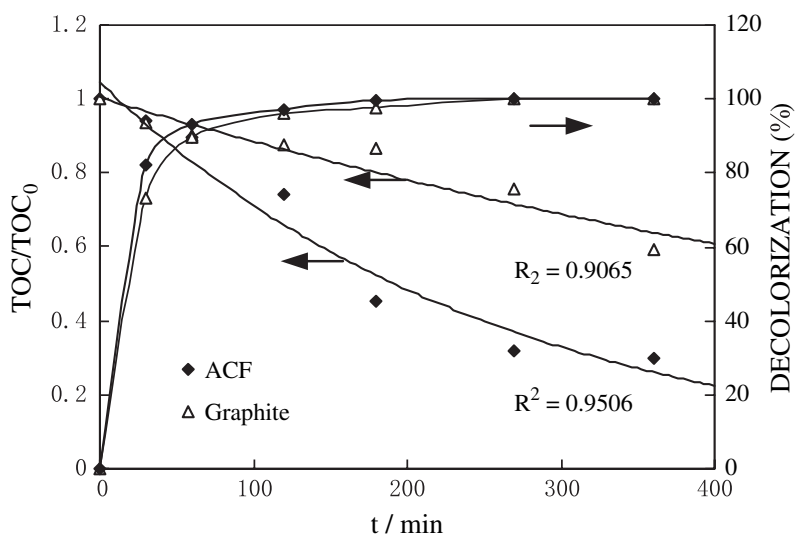

Fig. 3. Influence of cathode material on the removal of color and TOC. Applied current: $0.36 \mathrm{~A}$.

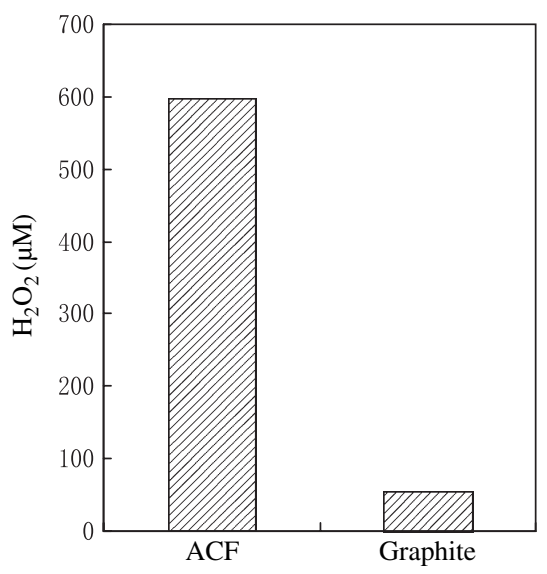

Fig. 4. Influence of different material cathodes on $\mathrm{H}_{2} \mathrm{O}_{2}$ generation amount of 180 min electrolysis.

which indicated that ACF was a favorable cathode material for $\mathrm{H}_{2} \mathrm{O}_{2}$ electrogeneration. This phenomenon could be likely explained by the fact that the ACF felt had large specific area of $1237 \mathrm{~m}^{2} \mathrm{~g}^{-1}$ and had a great number of mesoporous pores, so that $\mathrm{O}_{2}$ might be electroreducted easily on the cathode surface and generate more $\mathrm{H}_{2} \mathrm{O}_{2}$. The increasing $\mathrm{H}_{2} \mathrm{O}_{2}$ concentration might result in the more $\mathrm{OH}^{*}$ generated from electro-Fenton reaction. Therefore the mineralization of AR14 by ACF felt cathode was more complete than that of graphite cathode, and ACF felt was chosen as the electro-Fenton cathode in the following experiments.

\subsection{Comparative removal by adsorption, anodic oxidation and electro-Fenton reaction}

Fig. 5 summarizes the results of TOC decay relative to AR14 degradation by: (a) ACF cathode adsorption; (b) $\mathrm{RuO}_{2} / \mathrm{Ti}$ anodic oxidation; (c) oxidation by electrogenerated $\mathrm{H}_{2} \mathrm{O}_{2}$ in the absence of $\mathrm{Fe}^{2+}$; and (d) electroFenton conditions. The applied current was constant at 


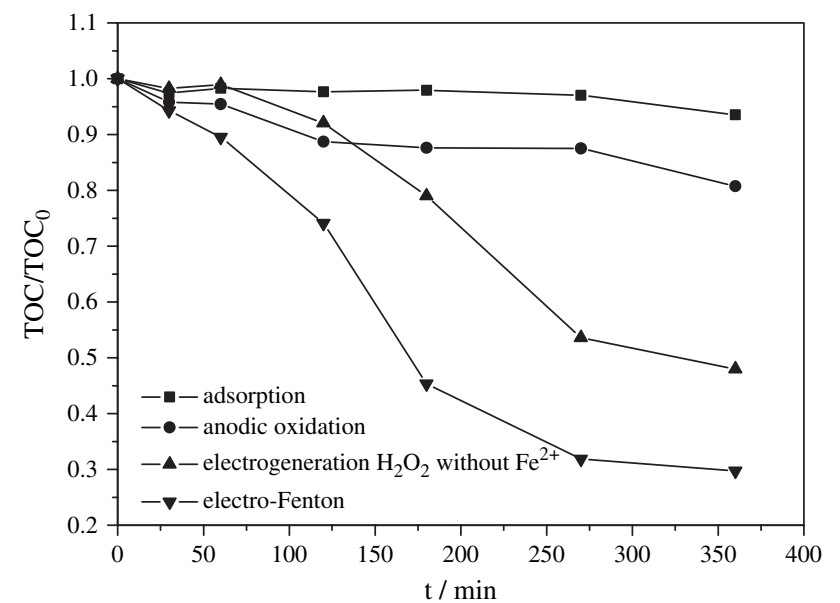

Fig. 5. TOC reduction as a function of treatment time for the ACF cathode adsorption, for the $\mathrm{RuO}_{2} / \mathrm{Ti}$ anodic oxidation, for oxidation by electrogenerated $\mathrm{H}_{2} \mathrm{O}_{2}$ in absence of $\mathrm{Fe}^{2+}$ and for the electroFenton conditions.

$0.36 \mathrm{~A}$. As could be seen, the use of ACF felt adsorption alone on AR14 led to a limiting removal of about $6 \%$ after $360 \mathrm{~min}$. Similarly anodic oxidation alone could only reduce TOC less than the $19 \%$. The low adsorption ability was attributed to the ACF felt that had been presaturated before every experiment. The low oxidative ability of anodic oxidation could be explained by the lower $\mathrm{OH}^{*}$ concentration formed on the $\mathrm{RuO}_{2} / \mathrm{Ti}$ anode surface, which was the main oxidizing agent of AR14 and its oxidation products in both the cases. The enhancement of the decomposition rate of AR14 using the ACF felt cathode pointed to a significant reaction of such organics with $\mathrm{H}_{2} \mathrm{O}_{2}$. In contrast, the electro-Fenton method with $1 \mathrm{mM} \mathrm{Fe}^{2+}$ had a much higher oxidative ability, since the TOC of the solution was reduced by $70 \%$ after $360 \mathrm{~min}$ of electrolysis. The significant acceleration in the presence of $\mathrm{Fe}^{2+}$ could be ascribed to the existence of fast homogeneous reaction of organics with the great amounts of $\mathrm{OH}^{*}$ generated from reaction (2), which could oxidize nonselectively most products remaining in the solution.

\subsection{UV-vis spectra changes in electro-Fenton process}

To clarify the changes of molecular and structural characteristics of AR14 as a result of electrolysis, representative UV-vis spectra changes of the dye solution as a function of electrolysis time were depicted in Fig. 6. As could be observed from these spectra, before the treatment, the absorption spectrum of AR14 in water was characterized by one main band in the visible region, with its maximum absorption at $514 \mathrm{~nm}$, and by two bands in the ultraviolet region located at 220 and $322 \mathrm{~nm}$. The peaks at 220 and $322 \mathrm{~nm}$ were ascribed

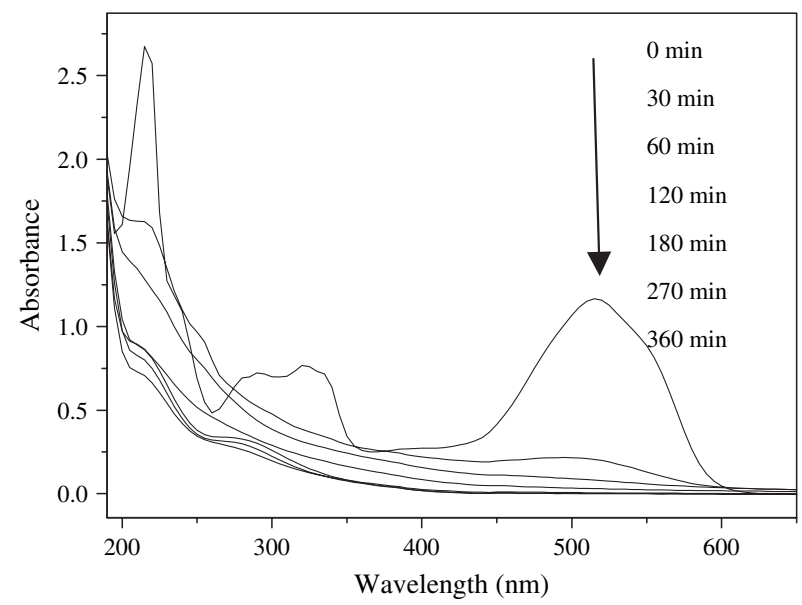

Fig. 6. UV-vis spectral changes with electrolysis time for $500 \mathrm{ml}$ of $200 \mathrm{mg} \mathrm{l}^{-1}$ AR14 solution in $0.05 \mathrm{M} \mathrm{Na}_{2} \mathrm{SO}_{4}$ of $\mathrm{pH}$ 3.0. Experimental conditions: applied current: $0.36 \mathrm{~A} ;\left[\mathrm{Fe}^{2+}\right]=1 \mathrm{mM}$ (samples were diluted for 5 -folds before monitoring).

to the absorption of the $\pi-\pi^{*}$ transition related to the naphthalene rings bonded to the $-\mathrm{N}=\mathrm{N}-$ group in the dye molecule $[21,22]$. The band in the visible region was attributed to the chromophore-containing azo linkage of the dye molecules in the solution [23]. The adsorption peak at $\lambda=514 \mathrm{~nm}$ diminished and finally disappeared completely under $360 \mathrm{~min}$ of electrolysis, indicating a rapid degradation of AR14. The decrease was also meaningful with respect to the $-\mathrm{N}=\mathrm{N}-$ bond of the azo dye, as a most active site for attack [24]. The intensity of absorption between 210 and $322 \mathrm{~nm}$ also gradually decreased during the electrochemical treatment, which indicated the destruction of the naphthalene rings. The transition of the UV-vis adsorption spectra of AR14 confirmed that electro-Fenton method was an effective electrochemical treatment for dyecontaining wastewater to some extent.

\subsection{Hydrogen peroxide electrogeneration in electro-Fenton process}

The ability of the electrolytic system to accumulate hydrogen peroxide supplied by the ACF felt cathode from reaction (1) was studied by determining the concentration of accumulated $\mathrm{H}_{2} \mathrm{O}_{2}$. Several electrolyses of $0.05 \mathrm{M} \mathrm{Na}_{2} \mathrm{SO}_{4}$ and initial $\mathrm{pH} 3.0$ solutions were carried out in the absence of $\mathrm{Fe}^{2+}$. These trials were performed with an ACF felt cathode at different current intensities. Fig. 7 presents the production of $\mathrm{H}_{2} \mathrm{O}_{2}$ at different current intensities. As shown in Fig. 7, it suggested a gradual rise in $\mathrm{H}_{2} \mathrm{O}_{2}$ concentration with the current increasing from 0.12 to $0.50 \mathrm{~A}$ during the initial 60 min of electrolysis. However, $\mathrm{H}_{2} \mathrm{O}_{2}$ concentration did not increase linearly with time. After approximately $60 \mathrm{~min}$, the accumulated $\mathrm{H}_{2} \mathrm{O}_{2}$ reached steady-state concentrations and remained almost constant. There 


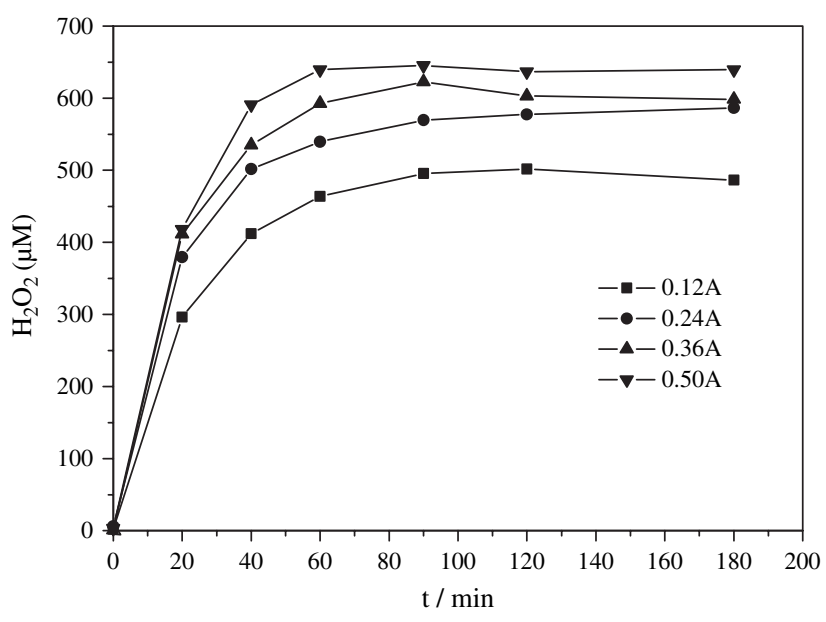

Fig. 7. $\mathrm{H}_{2} \mathrm{O}_{2}$ concentration with electrolysis time at different current using ACF as cathode. $\mathrm{O}_{2}$ flux $100 \mathrm{ml} \mathrm{min}^{-1}$.

was a mechanism for the decomposition of the hydrogen peroxide in the cell, even though no $\mathrm{Fe}(\mathrm{II})$ was deliberately added in the cell [25]. $\mathrm{H}_{2} \mathrm{O}_{2}$ could undergo chemical decomposition to $\mathrm{O}_{2}$ either on the anode (heterogeneous process) or in the medium (homogeneous process) (Eq. (5)) [26,27]. And $\mathrm{H}_{2} \mathrm{O}_{2}$ could also be anodically oxidized to yield intermediate $\mathrm{HO}_{2}{ }_{2}$ radicals (Eqs. (6) and (7)) [28]. In the steady state, $\mathrm{H}_{2} \mathrm{O}_{2}$ was electrogenerated and simultaneously destroyed in the system at the same rate.

$$
\begin{aligned}
& \mathrm{H}_{2} \mathrm{O}_{2} \rightarrow \mathrm{H}_{2} \mathrm{O}+1 / 2 \mathrm{O}_{2} \\
& \mathrm{H}_{2} \mathrm{O}_{2} \rightarrow \mathrm{HO}_{2}^{+}+\mathrm{H}^{+}+\mathrm{e}^{-} \\
& \mathrm{HO}_{2} \rightarrow \mathrm{O}_{2}+\mathrm{H}^{+}+\mathrm{e}^{-}
\end{aligned}
$$

\subsection{Influence of applied current on the AR14 removal by electro-Fenton process}

The influence of applied current upon degradative behaviors was examined by electrolyzing the above $200 \mathrm{mg}^{-1}$ AR14 solution of $\mathrm{pH} 3.0$ at $0.12,0.24,0.36$ and $0.50 \mathrm{~A}$. TOC decays of $500 \mathrm{ml}$ AR 14 solution with $1 \mathrm{mM} \mathrm{Fe}^{2+}$ by the electro-Fenton process with a $\mathrm{RuO}_{2} /$ Ti anode at several currents were depicted in Fig. 8. It was noted that after $360 \mathrm{~min}$ treatment the TOC removal was $34.4 \%$ at $0.12 \mathrm{~A}$, while at $0.24,0.36$ and $0.50 \mathrm{~A}$ the TOC removals were $64.9 \%, 70.3 \%$ and $73.3 \%$, respectively. When the applied current increased a more rapid decay of TOC took place. As discussed above, the increasing applied current could enhance the production of electrogenerated $\mathrm{H}_{2} \mathrm{O}_{2}$. The acceleration in degradation with increasing the applied current could be explained by the higher production of $\mathrm{OH}^{*}$ in the medium from Eq. (8) in which the instantaneous

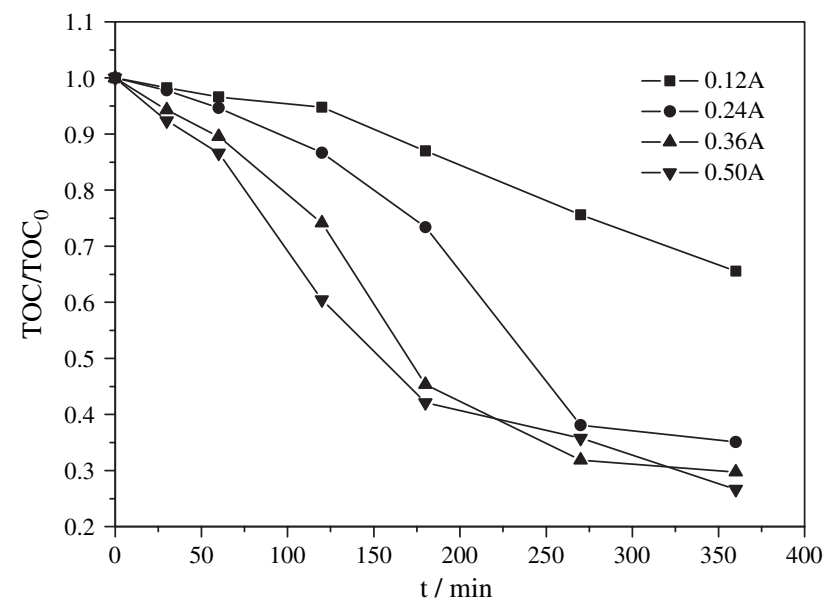

Fig. 8. Influence of the applied current upon TOC abatement of a $500 \mathrm{ml}$ solution containing $200 \mathrm{mg} \mathrm{l}^{-1} \mathrm{AR} 14$ and $1 \mathrm{mM} \mathrm{Fe}^{2+}$ in $0.05 \mathrm{M} \mathrm{Na}_{2} \mathrm{SO}_{4}$ of $\mathrm{pH} 3.0$ by electro-Fenton reaction.

concentration of hydroxyl radicals was proportional to the $\mathrm{H}_{2} \mathrm{O}_{2}$ concentration [29]

$\left[\mathrm{OH}^{\bullet}\right]=\lambda\left(\frac{\mathrm{d}\left[\mathrm{OH}^{\bullet}\right]}{\mathrm{d} t}\right)_{g}=\lambda k_{1}\left[\mathrm{Fe}^{2+}\right]\left[\mathrm{H}_{2} \mathrm{O}_{2}\right]$

where $k_{1}$ is the second-order rate constant $\left(\mu \mathrm{M}^{-1} \min ^{-1}\right)$ of reaction (2), $\lambda$ is the average life of the hydroxyl radical (min), and $\left[\mathrm{Fe}^{2+}\right]$ and $\left[\mathrm{H}_{2} \mathrm{O}_{2}\right]$ are the concentrations of ferrous ion $(\mu \mathrm{M})$ and hydrogen peroxide $(\mu \mathrm{M})$, respectively.

\subsection{Effect of $\mathrm{Fe}^{2+}$ dosage on electro-Fenton process}

Fig. 9 showed the results of $200 \mathrm{mgl}^{-1}$ AR14 solutions treated by electro-Fenton oxidation for 360 min treatment as dosing $\mathrm{Fe}^{2+}$ from 0 to $2 \mathrm{mM}$ at the applied current $0.36 \mathrm{~A}$. An obvious increase of the rate of TOC decay was observed by adding $\mathrm{Fe}^{2+}$ ion into solution and raising initial $\mathrm{Fe}^{2+}$ concentrations from 0 to $1 \mathrm{mM}$ might result in an augment of TOC removal. For example, after 270 min of electrolysis the TOC removals were $36.4 \%, 56.3 \%, 68.2 \%$ for $0,0.5$ and $1 \mathrm{mM} \mathrm{Fe}^{2+}$ solution, respectively. But when the $\mathrm{Fe}^{2+}$ concentration increased to $2 \mathrm{mM}$, the TOC abatement might decrease, and only $54.5 \%$ of the TOC was removed after $270 \mathrm{~min}$ of electrolysis. This agreed with the fact that the initial $\mathrm{Fe}^{2+}$ was rapidly transformed into $\mathrm{Fe}^{3+}$ from reaction (2), so that the continuous production of oxidizing $\mathrm{OH}^{*}$ was regulated by the small catalytic amount of regenerated $\mathrm{Fe}^{2+}$ in the medium. The influence of higher $\mathrm{Fe}^{2+}$ concentration upon the degradation behavior of AR14 could be explained by the percentage of the hydroxyl radicals that was scavenged by the $\mathrm{Fe}^{2+}$ as shown in Eq. (9) [30]. The $\mathrm{Fe}^{3+}$ formed also could react with $\mathrm{H}_{2} \mathrm{O}_{2}$ as well as with hydroperoxy radicals resulting in decrease in TOC 


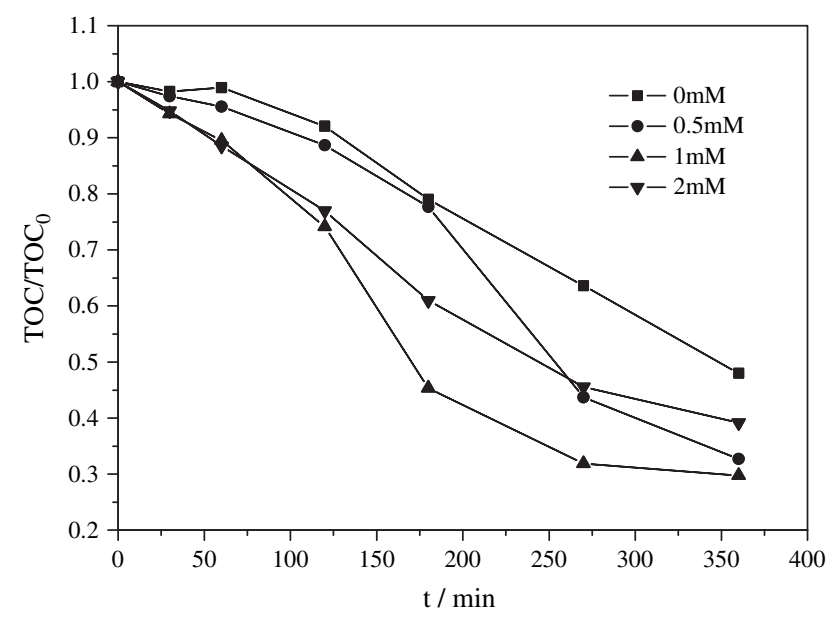

Fig. 9. TOC decay vs time for electrolyzed $200 \mathrm{mg} \mathrm{l}^{-1}$ AR 14 solution in $0.05 \mathrm{M} \mathrm{Na}_{2} \mathrm{SO}_{4}$ of $\mathrm{pH} 3.0$ by electro-Fenton reaction with different $\mathrm{Fe}^{2+}$ concentrations.

removal (Eqs. (10) and (11)) [31]. Consequently the suitable concentration of ferrous ion was an important prerequisite in the electro-Fenton reaction.

$$
\begin{aligned}
& \mathrm{Fe}^{2+}+\mathrm{OH}^{\cdot} \rightarrow \mathrm{Fe}^{3+}+\mathrm{OH}^{-} \\
& \mathrm{Fe}^{3+}+\mathrm{H}_{2} \mathrm{O}_{2} \leftrightarrow \mathrm{Fe}-\mathrm{OOH}^{2+}+\mathrm{H}^{+} \\
& \mathrm{Fe}-\mathrm{OOH}^{2+} \rightarrow \mathrm{HO}_{2}^{-}+\mathrm{Fe}^{2+}
\end{aligned}
$$

\section{Conclusions}

It had been confirmed that azo dye AR14 in aqueous solutions could be effectively mineralized by the hydroxyl radical during electro-Fenton method using ACF felt cathode. Based on experimental results presented above, the following conclusions were drawn:

1. More $\mathrm{H}_{2} \mathrm{O}_{2}$ could be generated on ACF felt cathode than graphite cathode. Although the decolorization rate of both the materials was almost the same, TOC could be reduced by about $70 \%$ by ACF felt cathode, while the TOC removal rate of graphite cathode was only $40 \%$. This was mainly because the large surface area of ACF felt could electrogenerate $\mathrm{H}_{2} \mathrm{O}_{2}$ more easily on ACF felt cathode than that of graphite cathode. ACF felt was a better cathode material for electro-Fenton process.

2. The mineralization of AR14 by electro-Fenton reaction was achieved efficiently using the ACF felt cathode. In the presence of $\mathrm{Fe}(\mathrm{II})$ as a catalyst, it brought about the facile removal of TOC with azo dye AR14. At pH 3.0 and applied current $0.36 \mathrm{~A}$, after $360 \mathrm{~min}$ of electrolysis the TOC removal rate for $500 \mathrm{ml}$ of a $200 \mathrm{mg}^{-1}$ AR14 in solution was $70 \%$.
3. The performance of the system was strongly dependent on the working conditions. Applied current and ferrous ion concentration were closely bound together and had significant effect on the degradation of AR14 by electro-Fenton reaction.

\section{Acknowledgements}

The authors gratefully acknowledge the financial support of this work by National Science Fund for Distinguished Young Scholars (No. 50225824) and National Natural Science Foundation of China (20337020).

\section{References}

[1] Prevot AB, Baiocchi C, Brussino M, Pramauro E, Savarino P, Augugliaro V, et al. Photocatalytic degradation of acid blue 80 in aqueous solutions containing $\mathrm{TiO}_{2}$ suspensions. Environ Sci Technol 2001;35:971-6.

[2] Rajeshwar K, Ibanez JG, Swain GM. Electrochemistry and the environment. J Appl Electrochem 1994;24:1077-91.

[3] Simonsson D. Electrochemistry for a cleaner environment. Chem Soc Rev 1997;26:181-9.

[4] Alverez-Gallegos A, Pletcher D. The removal of low level organics via hydrogen peroxide formed in a reticulated vitreous carbon cathode cell. Part 1: The electrosynthesis of hydrogen peroxide in aqueous acidic solutions. Electrochim Acta 1998;44:853-61.

[5] Alverez-Gallegos A, Pletcher D. The removal of low level organics via hydrogen peroxide formed in a reticulated vitreous carbon cathode cell. Part 2: The removal of phenols and related compounds from aqueous effluents. Electrochim Acta 1999;44: 2483-92.

[6] Panizza M, Cerisola G. Removal of organic pollutants from industrial wastewater by electrogenerated Fenton's reagent. Water Res 2001;35:3987-92.

[7] Ventura A, Jacquet G, Bermond A, Camel V. Electrochemical generation of the Fenton's reagent: application to atrazine degradation. Water Res 2002;36:3517-22.

[8] Brillas E, Mur E, Sauleda R, Sanchez L, Peral J, Domenech X, et al. Aniline mineralization by AOP's: anodic oxidation, photocatalysis, electro-Fenton and photoelectro-Fenton processes. Appl Catal B: Environ 1998;16:31-42.

[9] Brillas E, Casado J. Aniline degradation by electro-Fenton ${ }^{\circledR}$ and peroxi-coagulation processes using a flow reactor for wastewater treatment. Chemosphere 2002;47:241-8.

[10] Brillas E, Boye B, Banos MA, Calpe JC, Garrido JA. Electrochemical degradation of chlorophenoxy and chlorobenzoic herbicides in acidic aqueous medium by the peroxi-coagulation method. Chemosphere 2003;51:227-35.

[11] Boye B, Dieng MM, Brillas E. Degradation of herbicide 4-chlorophenoxyacetic acid by advanced electrochemical oxidation methods. Environ Sci Technol 2002;36:3030-5.

[12] Oturan MA, Peiroten J, Chartrin P, Acher AJ. Complete destruction of $p$-nitrophenol in aqueous medium by electroFenton method. Environ Sci Technol 2000;34:3474-9.

[13] Oturan MA, Pinson J, Oturan N, Deprez D. Hydroxylation of aromatic drugs by the electro-Fenton method. Formation and identification of the metabolites of Riluzole. New J Chem 1999;23: 793-4. 
[14] Oturan MA, Pinson J. Hydroxylation by electrochemically generated $\mathrm{OH}^{-}$radicals. Mono- and polyhydroxylation of Benzoic acid: products and isomers' distribution. J Phys Chem 1995;99: 13948-54.

[15] Oturan MA. An ecologically effective water treatment technique using electrochemically generated hydroxyl radicals for in situ destruction of organic pollutants: application to herbicide 2,4-D. J Appl Electrochem 2000;30:475-82.

[16] Rodger JD, Bunce NJ. Electrochemical treatment of 2,4,6trinitrotoluene and related compounds. Environ Sci Technol 2001;35:406-10.

[17] Conway BE, Ayranci E, Al-Maznai H. Use of quasi-3-dimensional porous electrodes for adsorption and electrocatalytic removal of impurities from waste-waters. Electrochim Acta 2001;47:705-18.

[18] Jia JP, Yang J, Liao J, Wang WH, Wang ZJ. Treatment of dyeing wastewater with ACF electrodes. Water Res 1999;33:881-4.

[19] Drogui P, Elmaleh S, Rumeau M, Rambaud A. Hydrogen peroxide production by water electrolysis: application to disinfection. J Appl Electrochem 2001;31:877-82.

[20] Ge JT, Qu JH. Ultrasonic irradiation enhanced degradation of azo dye on $\mathrm{MnO}_{2}$. Appl Catal B: Environ 2004;47:133-40.

[21] Wu F, Deng NS, Hua HL. Degradation mechanism of azo dye C.I. reactive red 2 by iron powder reduction and photooxidation in aqueous solutions. Chemosphere 2000;41:1233-8.

[22] Xiong Y, Strunk PJ, Xia HY, Zhu XH, Karlsson HT. Treatment of dye wastewater containing acid orange II using a cell with three-phase three-dimensional electrode. Water Res 2001;35: 4226-30.
[23] Stylidi M, Kondarides DI, Verykios XE. Pathways of solar lightinduced photocatalytic degradation of azo dyes in aqueous $\mathrm{TiO}_{2}$ suspensions. Appl Catal B: Environ 2003;40:271-86.

[24] Daneshvar N, Salari D, Khataee AR. Photocatalytic degradation of azo dye acid red 14 in water: investigation of the effect of operational parameters. J Photochem Photobiol A 2003;157: $111-6$.

[25] Harrington T, Plecher D. The removal of low levels of organics from aqueous solutions using $\mathrm{Fe}(\mathrm{II})$ and hydrogen peroxide formed in situ at gas diffusion electrodes. J Electrochem Soc 1999; 146:2983-9.

[26] Brillas E, Bastida RM, Liosa E, Casado J. Electrochemical destruction of aniline and 4-chloroaniline for wastewater treatment using a carbon-PTFE-fed cathode. J Electrochem Soc 1995; 142:1733-41.

[27] Brillas E, Mur E, Casado J. Iron (II) catalysis of the mineralization of aniline using a carbon-PTFE $\mathrm{O}_{2}$-fed cathode. J Electrochem Soc 1996; 143:L49-53.

[28] Brillas E, Calpe JC, Casado J. Mineralization of 2,4-D by advanced electrochemical oxidation processes. Water Res 2000; 34:2253-62.

[29] Wang Q, Lemley AT. Kinetic model and optimization of 2,4-D degradation by anodic Fenton treatment. Environ Sci Technol 2001;35:4509-14.

[30] Benitez FJ, Acero JL, Real FJ, Rubio FJ, Leal AI. The role of hydroxyl radicals for the decomposition of $p$-hydroxy phenylacetic acid in aqueous solutions. Water Res 2001;35:1338-43.

[31] Neyens E, Baeyens J. A review of classic Fenton's peroxidation as an advanced oxidation technique. J Hazard Mater 2003;98:33-50. 